UDC 661.666:66.096.5

\author{
A.V. Sybir ${ }^{a}$, S.S. Fedorov ${ }^{a}$, M.V. Hubynskyi ${ }^{b}$, S.M. Hubynskyi ${ }^{b}$, S.V. Koval ${ }^{a}$, K.M. Sukhyy ${ }^{c}$, \\ S.M. Foris ${ }^{a}$
}

\title{
THERMAL PURIFICATION OF NATURAL GRAPHITE BY MEANS OF HIGH-SPEED HEATING
}

\author{
${ }^{a}$ National Metallurgical Academy of Ukraine, Dnipro, Ukraine \\ b Thermal and Material Engineering Center Ltd., Dnipro, Ukraine \\ c Ukrainian State University of Chemical Technology, Dnipro, Ukraine
}

\begin{abstract}
The thermal method for the cleaning of carbon materials in an electrothermal fluidized bed belongs to the «green» technologies for producing graphite for the manufacture of anodes of lithium-ion batteries. The technology involves a rapid heating of the feedstock particles to the specified processing temperatures. The aim of the work was to simulate the thermal cleaning of carbon materials in electrothermal fluidized bed and choose such modes for the treatment of natural graphite that will ensure carbon content in the finished product of at least $99.95 \%$. To achieve the goal, a $5 \mathrm{~kW}$ laboratory resistive furnace was developed. While processing carbon samples weighing up to $30 \mathrm{~g}$, the reactor simulates the operating conditions that arise during fast heating to $3000^{\circ} \mathrm{C}$ in a fluidized bed in an inert gas atmosphere. A typical multistage purification cycle in laboratory conditions included the heating of the material during $0.5-1 \mathrm{~min}$ and holding it at a constant temperature for 5-15 min. The production mode was controlled based on the dependences of the operating temperature on the power consumption obtained by the «witness» method. The laboratory study of the thermal purification of natural graphite from the Zavallevsky deposit was carried out. The composition of the processed samples was determined by elemental analysis using a spectrometer and by measuring the ash after combustion of the samples. As a result of the study, acceptable parameters of the operating modes were determined, in particular, the temperature of $2900-3100^{\circ} \mathrm{C}$ and the processing time of $15 \mathrm{~min}$, which ensure the manufacture of high-quality product with a carbon content of at least $99.95 \%$.
\end{abstract}

Keywords: natural graphite, thermal purification, operating modes, fast heating, laboratory furnace.

DOI: $10.32434 / 0321-4095-2020-130-3-178-182$

\section{Introduction}

One of the reasons why the demand in highquality graphite has shown steady growth during the recent decades is the booming development of chemical power sources, wherein this material is utilized for anodes. In experts' opinion [1,2], the current production dynamics of electric vehicles, electronic and energy storage devices can result in shortages of such strategic material in the near future. Therefore, sustainable mining, processing, application and recycling of high-quality graphite are the top priority for the most developed countries. Meanwhile, Ukraine features the expanding market of electric batteries and relevant graphite resources, which makes the issue highly important for the state.
Along with such existing technologies of graphite purification to battery grade as acid and chlorine treatment, the high-temperature electrothermal fluidized bed processing (EFB), developed by Thermal and Material Engineering Center and National Metallurgical Academy of Ukraine [3-5], deserves special consideration. The technology allows treating carbon powder at temperatures up to $3000^{\circ} \mathrm{C}$ in continuous mode. It resolves purification and graphitization tasks consuming only electric power with possible integration of renewables. The latter can potentially result in the synthesis of high-quality almost «green» graphite with a low environmental footprint. However, due to the variety of available raw materials, 
the EFB technology still requires justified operating modes for each specific case because they affect the energy consumption rate and product grade.

For example, the duration of heating of graphite powder in the EFB was theoretically evaluated in work [6]. It was concluded that it is quite enough to treat the material for $0.2-2.5 \mathrm{~s}$. Meanwhile, the results did not consider chemical kinetics. In Acheson furnaces, on the other hand, graphite wares loaded in bulk are treated at $2800-3000^{\circ} \mathrm{C}$ for hours [7]. Under such conditions, the ash content is reduced to $0.09-0.11 \%$.

In the fundamental research of thermal purification of various carbon granules [8], the level of $2000^{\circ} \mathrm{C}$ was reached in $60-90 \mathrm{~min}$ with a further exposure to higher temperatures for $30 \mathrm{~min}$. Depending on the material type, the ash content was reduced to $0.10-0.28 \%$.

Thus, to date, it remains unclear which EFB operating modes should be applied and what is the effect of high-speed heating on these modes.

\section{Experimental}

Development of the laboratory-scale reactor

In order to study thermal purification of carbon materials at the high-temperature EFB, a laboratory resistive furnace was developed. The furnace is intended to imitate the operating conditions during the emulsion phase of fluidized beds at temperature up to $3000^{\circ} \mathrm{C}$ in the inert gas atmosphere.

The whole laboratory unit (Figs. 1-3) consists of the furnace equipped with a material matrix/ heater, heat insulation and a jacket; the power supply system; and the inert gas supply system.

Technical characteristics of the furnace are as follows: rated electric power of $5.0 \mathrm{~kW}$; electric supply voltage of $220 \mathrm{~V}(50 \mathrm{~Hz})$; voltage of furnace electrodes

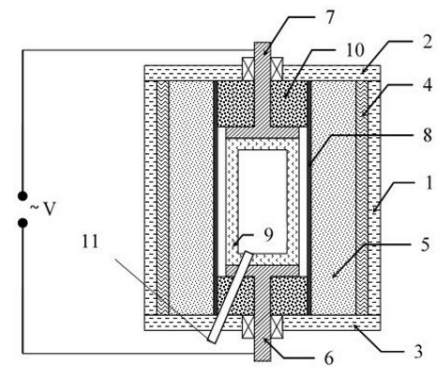

a

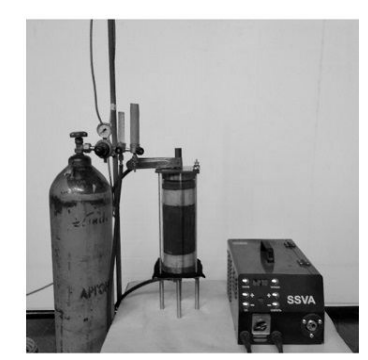

b
Fig. 1. The laboratory furnace for thermal purification of carbon materials: a - concept design; b - general view.

1, 2, 3 - furnace jacket made of stainless steel; 4 - soft thermal insulation; 5 - bulk thermal insulation (carbon black); 6, 7 - lower and upper graphite electrodes; 8 - graphite ring; 9 - high-resistive heater (carbon composite); 10 - soft carbon sealing; 11 - duct for exhaust gases of 16-22 V; operating current (secondary circuit) of 50 A (drying/heating) and 100-230 A (thermal treatment); and maximum weight of a sample of $30 \mathrm{~g}$. The furnace has a resistive indirect kind of the heating system. The kind of the gas supply system is a gas ramp with cylinders, reducing valve, float-type flowmeter, flow control valve, piping system, and pressure sensor. The unit is also equipped with the electric current control panel and temperature monitoring system.

\section{Commissioning tests of the reactor}

At the first stage of commissioning, the performance of resistive heaters was checked. For this purpose, the heat insulation and furnace jacket were taken off the unit. Thus, the heating was performed with a transparent quartz shell (Fig. 2). According to the test results, the maximum nondestructive electric current provided by the power supply system and heaters was $250 \mathrm{~A}$. The service life of the applied heating elements, made of special carbon composites, was more than 25 successive treatment cycles.

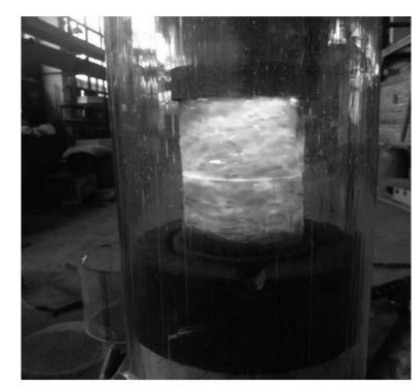

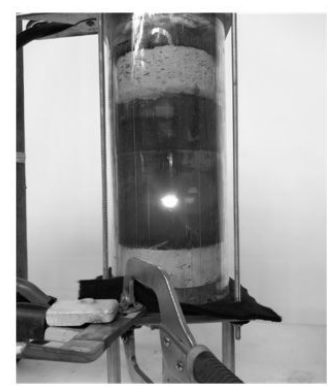

b
Fig. 2. Commissioning test of the resistive heater (current of $210 \mathrm{~A}$ and voltage of $21 \mathrm{~V}$ ): a - without insulation; $\mathrm{b}$ - with insulation

The operating curve of the device in the form of a dependence of the temperature on the consumed power was built based on the so-called «witness» method. For this purpose, we used materials with the known melting point listed in Table 1. During the experiments, additional monitoring of the heater temperature was also carried out by a pyrometer through the special aperture (Fig. 2). Each sample of nearly $3 \mathrm{~g}$ weight was subjected to a series of heating up at different current rate until full melting. The established step of the current was 5 A. The obtained results are shown as a chart in Fig. 3.

\section{Graphite purification}

To meet the set objectives, the material studied in this particular lab-scale purification technology was Zavallevsky graphite GEO-92. 
Table 1

Tested materials for the operating curve

\begin{tabular}{l|c}
\hline \multicolumn{1}{c|}{ Material } & Melting point, ${ }^{0} \mathrm{C}$ \\
\hline $\mathrm{Cu}$ & 1085 \\
\hline $\mathrm{AISI} 304$ & $1400-1450$ \\
\hline $\mathrm{Al}_{2} \mathrm{O}_{3}$ & 2072 \\
\hline $\mathrm{Alloy} \mathrm{WCo}-892 \%$. & 2780 \\
\hline $\mathrm{TiC}$ & 3257 \\
\hline
\end{tabular}

A typical multistage purification cycle comprised loading (5 min), heating up (0.5-1,0 min), steady treatment (optional duration for 5-15 min), cooling down (30 $\mathrm{min})$ and discharge $(5 \mathrm{~min})$ stages with total duration up to $40-50 \mathrm{~min}$. The established ranges for temperature and steady treatment time were $1400-3000^{\circ} \mathrm{C}$ and $5-15 \mathrm{~min}$, respectively. Each sample was weighed before and after the experiment. The chemical composition was tested by burning samples down at $1000^{\circ} \mathrm{C}$ (to determine the total ash content) as well as by the elemental analysis with a precision analyzer EXPERT $3 \mathrm{~L}$.

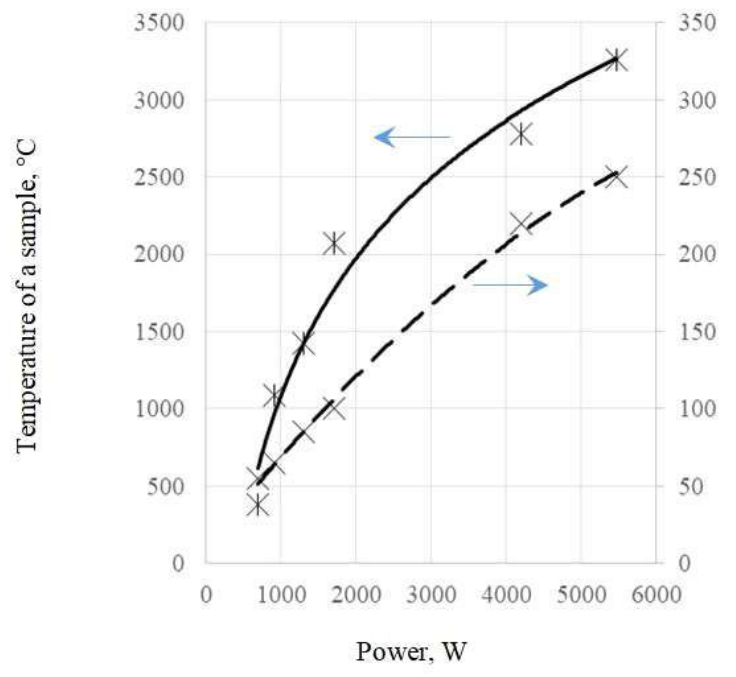

Fig. 3. The operating curve of the lab-scale furnace

\section{Results and discussion}

Typical results of the conducted purification are presented in Tables 2 and 3. During heating up, the reduction of the non-volatile oxides in the mineral part is observed at the temperatures higher than $1000^{\circ} \mathrm{C}$ [9]. Reduction products transfer directly to the gaseous phase or transform into high-melting carbon compounds (carbides) which evaporate later at higher temperatures. Therefore, the most noticeable reduction of mineral impurities in the experiments took place within the temperature range of 1400 to $2400^{\circ} \mathrm{C}$ (Table 2). The process featured rapid (several minutes long) formation of chemical deposits on the transparent quartz shell. The rest of the mineral compounds transformed into highmelting carbides resulting in slowdown of the purification rate. After each cycle, noticeable cracks were observed on the processed samples surface resulted from gaseous chemical compounds upward release (Fig. 4).

According to the obtained data from more the 30 purification cycles, the final ash content in the graphite was influenced mostly by the operating temperature. $\mathrm{Fe}, \mathrm{Ca}$ and $\mathrm{Ti}$ were elements that are hard to remove, which was linked to their relatively high initial concentration and their atomic weight.

Table 2

Ash content of graphite samples depending on operating temperatures (graphite GEO-92\%, duration of steady treatment $15 \mathrm{~min}$ )

\begin{tabular}{c|c|c}
\hline $\begin{array}{c}\text { Consumed } \\
\text { Power, } \mathrm{kW}\end{array}$ & $\begin{array}{c}\text { Operating } \\
\text { temperature, }{ }^{0} \mathrm{C}\end{array}$ & $\begin{array}{c}\text { Content of total } \\
\text { ash, \% }\end{array}$ \\
\hline 1.88 & $1400-1500$ & 5.81 \\
\hline 3.20 & $1700-2000$ & 3.50 \\
\hline 3.50 & $2000-2400$ & 1.24 \\
\hline 4.00 & $2600-2800$ & 0.11 \\
\hline 4.40 & $2900-3100$ & 0.03 \\
\hline
\end{tabular}

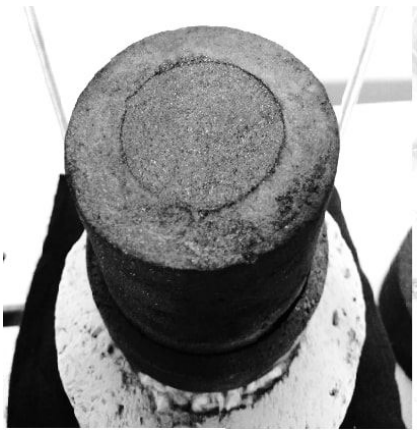

a

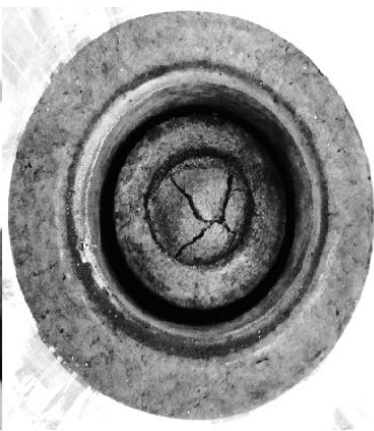

b
Fig. 4. The matrix filled with a sample of natural graphite: $\mathrm{a}-$ before treatment; $\mathrm{b}-$ after treatment

It should be pointed out that the temperature range securing purification of GEO-92 samples to battery grade $(>99.95 \%)$ was $2900-3100^{\circ} \mathrm{C}$. The final ash content was practically the same when the material was processed during 5-15 min at the same temperature, thus we can conclude that the purity of the samples insufficiently depended on the treatment duration. However, the operating modes up to 15 min duration steadily ensured the battery 
Table 3

Ash content before and after purification $\left(2900-3100^{\circ} \mathrm{C} / 15 \mathrm{~min}\right)$

\begin{tabular}{c|c|c|c}
\hline Components & Initial material & Purified & Units \\
\hline Total Ash & 10.58 & $<0.05$ & $\%$ \\
\hline $\mathrm{Al}$ & 7337.2 & - & $\mathrm{ppm}$ \\
\hline $\mathrm{Si}$ & 18134.1 & $<2.8$ & $\mathrm{ppm}$ \\
\hline $\mathrm{P}$ & 173.5 & - & $\mathrm{ppm}$ \\
\hline $\mathrm{S}$ & 1082.3 & - & $\mathrm{ppm}$ \\
\hline $\mathrm{K}$ & 2072.6 & - & $\mathrm{ppm}$ \\
\hline $\mathrm{Ca}$ & 1917.1 & $<11.1$ & $\mathrm{ppm}$ \\
\hline $\mathrm{Ti}$ & 453.9 & $<15.5$ & $\mathrm{ppm}$ \\
\hline $\mathrm{V}$ & 94.2 & $<2.2$ & $\mathrm{ppm}$ \\
\hline $\mathrm{Mn}$ & 280.4 & - & $\mathrm{ppm}$ \\
\hline $\mathrm{Fe}$ & 29377.5 & $<27.5$ & $\mathrm{ppm}$ \\
\hline $\mathrm{Cu}$ & 351.3 & - & $\mathrm{ppm}$ \\
\hline $\mathrm{Ni}$ & 45.5 & - & $\mathrm{ppm}$ \\
\hline $\mathrm{Zn}$ & 561.8 & $<1.2$ & $\mathrm{ppm}$ \\
\hline $\mathrm{As}$ & 15.9 & - & $\mathrm{ppm}$ \\
\hline $\mathrm{Mo}$ & 84.6 & $<4.3$ & $\mathrm{ppm}$ \\
\hline & & &
\end{tabular}

grade quality by the end of each cycle. It can be explained by the size of a sample $\varnothing 40 \times \mathrm{h} 30 \mathrm{~mm}$, leveling up the temperature field along the sample diameter and diffusion of impurities.

The obtained results of the research are to be used for further development of technical guidelines for thermal purification of Ukraine's natural graphite by the EFB technology.

\section{Conclusions}

The laboratory resistive furnace of $5 \mathrm{~kW}$ capacity intended to imitate the operating conditions occurring at the emulsion phase of the electrothermal fluidized bed at around $3000^{\circ} \mathrm{C}$ in the inert gas atmosphere was developed.

Based on the experimental study, it was shown that the most noticeable reduction of mineral impurities occurs in the temperature range of 1400 to $2400^{\circ} \mathrm{C}$. $\mathrm{Fe}, \mathrm{Ca}$ and $\mathrm{Ti}$ are elements that are hard to remove. The temperatures securing purification of natural graphite GEO-92 to battery grade $(>99.95 \%)$ is $2900-3100^{\circ} \mathrm{C}$. Final ash content slightly differed within 5-15 min purification at the same temperature, meanwhile the duration of $15 \mathrm{~min}$ should be considered as an upper limit mandatory for purification of a given material.

\section{REFERENCES}

1. Jewell S., Kimball S.M. Mineral commodity summaries. - Reston: U.S. Geological Survey, 2017. - 196 p.

2. Keeling J. Graphite: properties, uses and South Australian resources // MESA J. - 2017. - Vol.84. - No. 3. - P.28-41.

3. Ukraine's graphite perspectives in Li-ion battery supply chains / Fedorov S., Hubinsky S., Sybir A., Hubinskyi M. Foris S. // Proceedings of the Scientific and Technical International Conference «Information Technology in Metallurgy and Machine Building». - Dnipro. - 2019. - P.21-22.

4. The biomass utilization to obtain high-purity carbonaceous materials / Kieush L., Fedorov S., Koveria A., Sybir A. // Vybrani aspekty zabezpechenn'ya khimtechnologichnoyi nadiinosti tekhniky. - National Aviation University. - 2019. P.20-32.

5. Ultrahigh-temperature continuous reactors based on electrothermal fluidized bed concept / Fedorov S.S., Singh Rohatgi U., Barsukov I.V., Gubynskyi M.V., Barsukov M.G., Wells B.S., Livitan M.V., Gogotsi O.G. // J. Fluid. Eng. - 2015. - Vol.138. - Article No. 044502.

6. Osobennosti nagreva uglerodsoderzhaschego syr'ya v elektrotermicheskikh pechakh kipyaschego sloya / Fedorov S.S., Hubynskyi M.V., Tischenko T.A., Barsukov I. // Metallurgicheskaya i Gornorudnaya Promyshlennost. - 2015. No. 3. - P.103-107.

7. Ragan S., Marsh H. Science and technology of graphite manufacture // J. Mater. Sci. - 1983. - Vol.18. - No. 11. P.3161-3176.

8. Veselovskyi V.S., Pertse V.I. Issledovanie svoistv iskustvennogo grafita // Zhurnal Fizicheskoi Khimii. - 1934. Vol.5. - No. 5. - P.557-573.

9. Ostrovskyi V.S., Virgiliev Yu.S., Kostikov V.I. Iskusstvennyi grafit. - M.: Metallurgiya, 1986. - 272 p.

Received 02.03.2020 


\section{ТЕРМІЧНЕ ОЧИЩЕННЯ ПРИРОДНОГО ГРАФІТУ ШЛЯХОМ ВИСОКОШВИДКІСНОГО НАГРІВАННЯ}

\section{А.В. Сибір, С.С. Федоров, М.В. Губинський, С.М. Губинський, С.В. Коваль, К.М. Сухий, С.М. Форись}

Термічний метод очищення вуглецевих матеріалів в електротермічному псевдорозрідженому шарі належить до «зелених» технологій одержання графіту для виготовлення анодів літій-іонних акумуляторів. Технологія передбачає швидке нагрівання частинок сировини до заданих температур обробки. Метою даної роботи було моделювання термічного очищення вуглецевих матеріалів в електротермічному киплячому шарі та вибір режимів оброблення природного графіту, що забезпе чують вміст вуглецю у готовому продукті не менше 99,95\%. Для досягнення мети була розроблена лабораторна резистивна піч потужністю $5 \kappa$ Вт. При обробиі зразків вуглецю масою до 30 г реактор імітує робочі умови, що виникають при швидкому нагріванні до $3000^{\circ}$ С у киплячому шарі в атмосфері інертного газу. Типовий ступінчастий иикл очищення у лабораторних умовах включав нагрівання матеріалу протягом 0,5-1,0 хв витримування при постійній температурі протягом 5-15 хв. Режим оброблення контролювався на основі залежності робочої температури від споживаної потужності, одержаної ме тодом «свідчення». Здійснено лабораторне дослідження термічного очищення природного графіту з Завалевського родовища. Склад оброблених зразків визначали елементним аналізом на спектрометрі і визначенням попелу при згорянні зразків. У результаті були визначені прийнятні параметри режимів роботи, зокрема, температура $2900-3100^{\circ} \mathrm{C}$ і тривалість оброблення 15 хв, що забезпечують високу якість продукту із вмістом вуглецю не менше 99,95\%.

Ключові слова: природний графіт, термічне очищення, режими роботи, швидке нагрівання, лабораторна піч.

\section{THERMAL PURIFICATION OF NATURAL GRAPHITE BY MEANS OF HIGH-SPEED HEATING}

A.V. Sybir a, S.S. Fedorov ${ }^{a}$, M.V. Hubynskyi ${ }^{b,}$ * S.M. Hubynskyi ${ }^{b}$, S.V. Koval ${ }^{a}$, K.M. Sukhyy ${ }^{c}$, S.M. Foris ${ }^{a}$

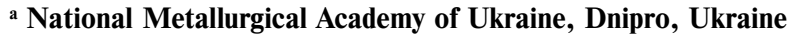
b Thermal and Material Engineering Center Ltd, Dnipro, Ukraine

c Ukrainian State University of Chemical Technology, Dnipro, Ukraine

\section{*e-mail: gubinmv@ukr.net}

The thermal method for the cleaning of carbon materials in an electrothermal fluidized bed belongs to the «green» technologies for producing graphite for the manufacture of anodes of lithium-ion batteries. The technology involves a rapid heating of the feedstock particles to the specified processing temperatures. The aim of the work was to simulate the thermal cleaning of carbon materials in electrothermal fluidized bed and choose such modes for the treatment of natural graphite that will ensure carbon content in the finished product of at least $99.95 \%$. To achieve the goal, a $5 \mathrm{~kW}$ laboratory resistive furnace was developed. While processing carbon samples weighing up to $30 \mathrm{~g}$, the reactor simulates the operating conditions that arise during fast heating to $3000^{\circ} \mathrm{C}$ in a fluidized bed in an inert gas atmosphere. A typical multistage purification cycle in laboratory conditions included the heating of the material during $0.5-1.0 \mathrm{~min}$ and holding it at a constant temperature for 5-15 min. The production mode was controlled based on the dependences of the operating temperature on the power consumption obtained by the «witness» method. The laboratory study of the thermal purification of natural graphite from the Zavallevsky deposit was carried out. The composition of the processed samples was determined by elemental analysis using a spectrometer and by measuring the ash after combustion of the samples. As a result of the study, acceptable parameters of the operating modes were determined, in particular, the temperature of $2900-3100^{\circ} \mathrm{C}$ and the processing time of $15 \mathrm{~min}$, which ensure the manufacture of high-quality product with a carbon content of at least $99.95 \%$.

Keywords: natural graphite; thermal purification; operating modes; fast heating; laboratory furnace.

\section{REFERENCES}

1. Jewell S., Kimball S.M., Mineral commodity summaries. U.S. Geological Survey, Reston, 2017. 196 p.

2. Keeling J. Graphite: properties, uses and South Australian resources. MESA Journal, 2017, vol. 84, no. 3, pp. 28-41.

3. Fedorov S., Hubinsky S., Sybir A., Hubinskyi M. Foris S., Ukraine's graphite perspectives in $\mathrm{Li}$-ion battery supply chains. Proceedings of the Scientific and Technical International Conference "Information Technology in Metallurgy and Machine Building», Ukraine, Dnipro, 2019, pp. 21-22.

4. Kieush L., Fedorov S., Koveria A., Sybir A., The biomass utilization to obtain high-purity carbonaceous materials. In: Vybrani aspekty zabezpechenn'ya khimtechnologichnoyi nadiinosti tekhniky. National Aviation University Publishers, Kyiv, 2019, pp. 20-32.

5. Fedorov S.S., Singh Rohatgi U., Barsukov I.V., Gubynskyi M.V., Barsukov M.G., Wells B.S., Livitan M.V., Gogotsi O.G. Ultrahigh-temperature continuous reactors based on electrothermal fluidized bed concept. Journal of Fluids Engineering, 2015, vol. 138, article no. 044502.

6. Fedorov S.S., Hubynskyi M.V., Tischenko T.A., Barsukov I. Osobennosti nagreva uglerodsoderzhaschego syr'ya v elektrotermicheskikh pechakh kipyaschego sloya [Features of heating carbon-containing raw materials in an electrothermal fluidized bed]. Metallurgicheskaya i Gornorudnaya Promyshlennost, 2015, no. 3, pp. 103-107. (in Russian).

7. Ragan S., Marsh H. Science and technology of graphite manufacture. Journal of Materials Science, 1983, vol. 18, pp. 31613176.

8. Veselovskyi V.S., Pertse V.I. Issledovanie svoistv iskustvennogo grafita [Study of the properties of artificial graphite]. Zhurnal Fizicheskoi Khimii, 1934, vol. 5, no. 5, pp. 557-573. (in Russian).

9. Ostrovskyi V.S., Virgiliev Yu.S., Kostikov V.I., Iskusstvennyi grafit [Artificial graphite]. Metallurgiya Publishers, Moscow, 1986. 272 p. (in Russian). 